\title{
Da alegria à revolta: a retórica das mídias para eliciar emoções nos brasileiros através de estereótipos
}

\section{From joy to rebellion: the rhetoric of the media to elicit emotions in Brazilians through stereotypes}

Fernando Simões Antunes Junior

Docente e bolsista de pós-doutorado do Programa de Pós-Graduação em Processos e Manifestações Culturais da Universidade Feevale, Brasil. Doutor pelo Programa de Pós-Graduação em Comunicação Social da Pontifícia Universidade Católica do Rio Grande do Sul, Brasil. E-mail: feuantunes@gmail.com

Jacques Alkalai Wainberg

Docente da Pontifícia Universidade Católica do Rio Grande do Sul. Paulo, Brasil. Doutor em Ciências da Comunicação pela Universidade de São Paulo, Brasil. Pós-doutor pela Universidade do Texas, Estados Unidos, e na Universidade de Tel Aviv, Israel. E-mail: jacqalwa@pucrs.br

\section{Resumo:}

O presente artigo pretende averiguar indícios de como o discurso midiático tem contribuído para a desconstrução do estereótipo do brasileiro feliz, agora mais raivoso e reativo, como recurso retórico para o regramento do humor das massas. A partir da análise de peças jornalísticas nacionais e internacionais, busca-se levantar hipóteses sobre a construção do clima emocional que permeou as discussões políticas e ideológicas acerca dos escândalos de corrupção que culminaram em um processo de impeachment da presidente da república Dilma Rousseff. Para esta breve análise, são utilizadas algumas bases teóricas compartilhadas entre a psicologia cognitiva, o pensamento sistêmico e a neurolinguística, de forma a promover um estudo interdisciplinar entre as ciências da mente, do corpo e da comunicação.

\section{Palavras-chave:}

Comunicação; Emoções; Retórica.

\begin{abstract}
:
This article aims to examine evidence of how the media has contributed to deconstruct the stereotype of the happy Brazilian, now angrier and reactive, as a rhetorical tool to hold sway over the mood of the masses. From the analysis of national and international news stories, we seek to raise hypotheses about the construction of the emotional environment that permeated the political and ideological discussions about the corruption scandals that culminated in the impeachment proceedings of President Dilma Rousseff. For this brief analysis, we used some theoretical bases originated from cognitive psychology, systems thinking and neurolinguistic, in order to promote an interdisciplinary study of the sciences of the mind, body and communication.
\end{abstract}

\section{Keywords:}

Communication; Emotions; Rhetoric. 


\section{Introdução}

Nos últimos anos, o estereótipo do brasileiro moldado ainda na década de 30, tido como um sujeito alegre e feliz por natureza (FREIRE FILHO, 2015a), tem sofrido fortes abalos. As manifestações sociais contra o aumento das passagens de ônibus, ocorridas no final de $2013^{1}$, o resultado das eleições de 2014 , que reelegeu Dilma Rousseff e levou o Partido dos Trabalhadores (PT) ao seu quarto mandato na disputa mais apertada da história do presidencialismo no Brasil ${ }^{2}$; a maior crise econômica enfrentada pelo país em 20 anos $^{3}$; e as consequentes manifestações organizadas por movimentos autodeclarados liberais em $2015 \mathrm{em} 2016^{4}$ foram os ingredientes que culminaram em uma ruptura entre setores da sociedade que fizeram transbordar manifestações raivosas nas redes sociais.

Coberturas classificadas como tendenciosas por parte da grande mídia e a guerra de informações e contrainformações entre ativistas pró-governo e antigoverno geraram um clima que transformou o panorama emocional do Brasil.

\footnotetext{
${ }^{1}$ Também conhecidas como Manifestações dos 20 centavos, Manifestações de Junho ou Jornadas de Junho. Referem-se às várias manifestações populares que inicialmente surgiram para contestar os aumentos nas tarifas de transporte público nas principais capitais. Ganharam apoio popular em meados de junho, após forte repressão policial contra os manifestantes, cujo ápice se deu em 13 de junho, quando milhões de brasileiros foram às ruas protestar não apenas pela redução das tarifas e contra a violência policial, mas também por uma grande variedade de temas como os gastos públicos em grandes eventos esportivos internacionais, a má qualidade dos serviços públicos e a indignação com a corrupção política em geral (JUDENSNAIDER et al., 2013).

${ }^{2}$ Após uma campanha de intensa polarização no segundo turno, a presidente Dilma Rousseff (PT) foi reeleita no dia 26 de outubro de 2014 e impediu a virada do senador mineiro Aécio Neves, candidato do PSDB. Dilma obteve $51,64 \%$ dos votos e Aécio, $48,36 \%$. A diferença de 3,4 milhões de votos foi a menor em um segundo turno desde a redemocratização. Antes disso, a disputa mais apertada fora em 1989, quando Fernando Collor de Mello (então no PRN) venceu Luiz Inácio Lula da Silva (PT) por 4 milhões de votos. Na época, Collor teve $53,03 \%$ contra $46,97 \%$ de Lula. Disponível em $<$ http://eleicoes.uol.com.br/2014/noticias/2014/10/26/dilma-cresce-na-reta-final-e-reeleita-e-emplacaquarto-mandato-do-pt.htm>. Acesso em: 07/06/2016.

${ }^{3}$ Em 2015 o Brasil mergulhou em uma forte recessão que se estendeu ao longo de 2016. O país fechou 1,5 milhão de postos de emprego com carteira assinada e em setembro de 2016 somava 12 milhões de desempregados entre a população ativa, segundo dados do IBGE. Disponível em $<$ http://g1.globo.com/economia/noticia/2016/08/desemprego-fica-em-116-no-trimestre-encerrado-emjulho.html $>$. Acesso em: 30/08/2016.

${ }^{4}$ Os grupos Vem Pra Rua, Movimento Brasil Livre (MBL) e Revoltados On Line se autodeclararam os organizadores das manifestações ocorridas em 2015 e 2016. Defendem pautas em comum como um estado mínimo, a separação dos três poderes, a consolidação de um regime parlamentarista e a existência de apenas cinco partidos no país. Disponível em $<$ http://exame.abril.com.br/brasil/noticias/quem-sao-e-o-que-pensam-os-lideres-dos-protestos-do-dia15>. Acesso em: 07/06/2016.
}

INTERIN, v. 22, n. 2, jul./dez. 2017. ISSN: 1980-5276. 
Agressões mútuas, términos de amizades e rompimentos de laços sociais inundaram as redes sociais. Ao mesmo tempo, revistas semanais estamparam manchetes passionais, carregadas de operadores retóricos, insuflando ainda mais uma reação dual da sociedade, rompendo com o jornalismo informativo para dar lugar a uma cobertura carregada de argumentos falaciosos.

Ao redor do globo, veículos de vários países ainda se perguntam What is going on with Brazil?, dando a entender que o então pacífico e alegre povo brasileiro estava a se transformar em uma massa raivosa. Para alguns analistas de sites internacionais, a crise econômica global que provocou a queda dos preços da soja, do petróleo e do minério de ferro, associada à crise política gerada por intermináveis denúncias de corrupção envolvendo membros do alto escalão do governo e de grande parte de deputados e senadores do Congresso e a consequente estagnação do mercado interno e das exportações foram apenas alguns dos componentes que colocaram o brasileiro em um estado alterado de humor. O ingrediente explosivo, na avaliação de alguns destes profisssionais de comunicação, seria a condução passional dos meios de comunicação de massa do Brasil que inflamaram os ânimos da sociedade (Fig.1).

Recentemente o jornal britânico The Guardian ${ }^{5}$, através de um artigo de opinião do ativista brasileiro David Miranda ${ }^{6}$, apontou o conservadorismo das famílias que concentram o poder midiático no Brasil como um dos principais causadores da desestabilização política e econômica pela qual passa o País. E destacou os incentivos destas organizações às manifestações raivosas e indignadas que tomaram destaque na mídia internacional. Diz o jornal:

\footnotetext{
Por um ano, esses mesmos grupos midiáticos têm vendido uma narrativa atraente: uma população insatisfeita, impulsionada pela fúria contra um governo corrupto, se organiza e demanda a derrubada da primeira presidente mulher do Brasil, Dilma Rousseff, e do Partido dos Trabalhadores (PT). O mundo viu inúmeras imagens de grandes multidões protestando nas ruas, uma visão sempre inspiradora (MIRANDA, 2016) ${ }^{7}$.

${ }^{5}$ Disponível em <http://www.theguardian.com/commentisfree/2016/apr/22/razao-real-que-os-inimigosde-dilma-rousseff-querem-seu-impeachment>. Acesso em: 07/06/2016.

${ }^{6}$ David Miranda é criador do Tratado Snowden, que visa defender o direito à privacidade dos indivíduos e elaborar normas contra a vigilância em massa promovida por governos e grandes corporações.

${ }^{7}$ Disponível em <http://www.theguardian.com/commentisfree/2016/apr/22/razao-real-que-osinimigos-de-dilma-rousseff-querem-seu-impeachment>. Acesso em: 07/06/2016.
}

INTERIN, v. 22, n. 2, jul./dez. 2017. ISSN: 1980-5276. 
Figura1: Site da BBC questiona mudança de humor do brasileiro

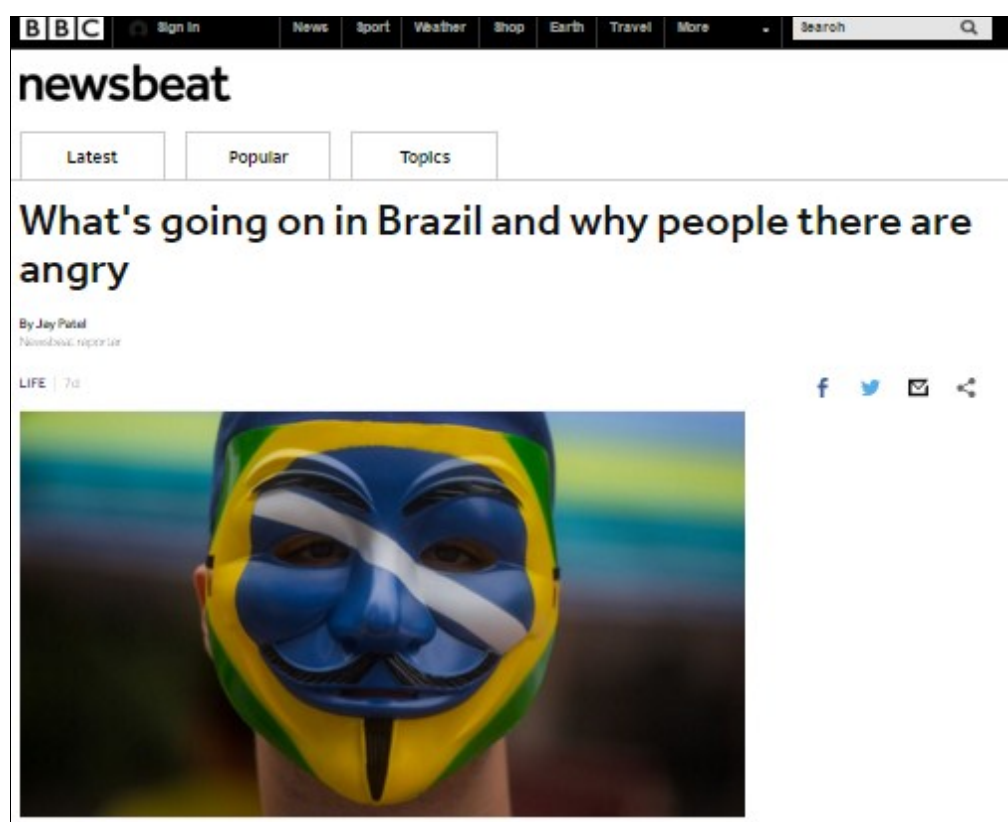

Fonte: screenshot da revista online Newsbeat ${ }^{8}$

Em outro trecho, David ataca o que seria uma nova tentativa de construção estereotipada da imagem do brasileiro, agora mais caricata e bidimensional, dando a entender que existem apenas dois tipos de pensamento orbitando o imaginário político nacional, o que seria irresponsável diante das consequências do que classificou como um "jogo perigoso", como mostra o trecho a seguir.

Por fim, as elites políticas e a mídia do Brasil têm brincado com os mecanismos da democracia. Isso é um jogo imprevisível e perigoso para se jogar em qualquer lugar, porém mais ainda em uma democracia tão jovem com uma história recente de instabilidade política e tirania, e onde milhões estão furiosos com a crise econômica que enfrentam (MIRANDA, 2016).

Alguns veículos optaram por retratar a repentina fúria dos brasileiros contrapondo imagens esperadas do estereótipo do brasileiro feliz com imagens de

\footnotetext{
8 Disponível em <http://www.bbc.co.uk/newsbeat/article/36024360/whats-going-on-in-brazil-andwhy-people-there-are-angry>. Acesso em: 07/06/2016.

9 Disponível em <http://www.theguardian.com/commentisfree/2016/apr/22/razao-real-que-osinimigos-de-dilma-rousseff-querem-seu-impeachment>. Acesso em: 07/06/2016.
}

INTERIN, v. 22, n. 2, jul./dez. 2017. ISSN: 1980-5276. 
torcedores protestando contra Dilma Rousseff no jogo de abertura da Copa do Mundo (Fig. 2).

Figura 2: Site da BBC coloca imagem estereotipada de alegria em contraposição ao ódio brasileiro
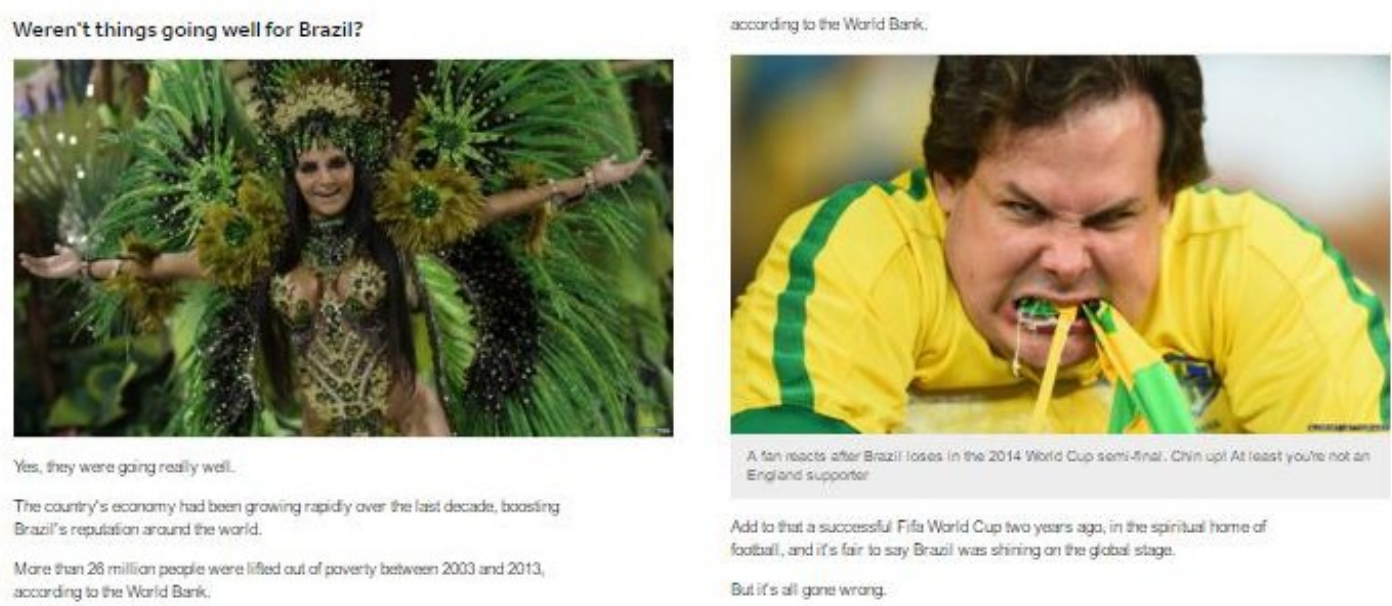

Fonte: recortes de screenshot da revista online Newsbeat ${ }^{10}$

O clima emocional resultante do "nós contra eles", em que o "nós" e o "eles" são construídos a partir de regras, limites e dogmas bem rígidos, faz com que qualquer deslize de discurso seja interpretado como afronta a um dos possíveis lados desta visão bidimensional, e qualquer posicionamento do sujeito pode catapultá-lo de um lado ao outro por detalhes semânticos.

Em meio à premissa de que esta bidimensionalidade, na qual vive atualmente o brasileiro, é supostamente alimentada pelo discurso midiático com forte reverberação nas redes sociais, identificamos, de um lado, o discurso "do golpe" defendido pelos que são contra o impeachment do governo de Dilma Rousseff, e de outro, o discurso da "limpa na corrupção" adotado pelos que pediram a saída da presidente petista do poder. Os que são contra o golpe adotam argumentos que questionam a parcialidade das investigações da Operação Lava Jato, da Polícia Federal, bem como todos os atos jurídicos e parlamentares subsequentes. Para este grupo, há um julgamento político institucionalizado em curso em uma tentativa de desestabilização do governo friamente orquestrada supostamente por setores políticos e econômicos insatisfeitos com o resultado das eleições em 2014. O ápice

${ }^{10}$ Idem anterior

INTERIN, v. 22, n. 2, jul./dez. 2017. ISSN: 1980-5276. 
desta desestabilização seriam as coligações entre partidos de oposição com partidos dissidentes do governo para que o poder executivo fosse tomado "de assalto" através de um processo de impeachment, que seria uma suposta roupagem de aparente legalidade para o que alegam ser um golpe político e, portanto, ilegítimo.

Do outro lado, grupos anti-governo organizados pela internet como o Movimento Brasil Livre (MBL) e o Revoltados Online afirmam defender um país livre de corrupção e culpam Dilma Rousseff e o governo do PT pelo aparelhamento generalizado que teria usurpado milhões dos cofres públicos nos últimos anos. Mensalão, Petrolão e outros propinodutos são citados como invenções petistas para servir aos interesses políticos e econômicos do PT. Ao mesmo tempo, estes grupos autoproclamados como apartidários dão apoio a deputados e senadores de partidos de oposição, muitos deles acusados de corrupção, acirrando ainda mais a visão dualística que se formou no cenário político brasileiro.

Em análises aleatórias em postagens destes grupos no Twitter e Facebook, é perceptível que ambos os discursos possuem incongruências e contradições em suas narrativas, fazendo-se valer inclusive de notícias falsas. Qualquer análise mais sóbria sobre os argumentos é sobrepujada por uma retórica que busca criar identificação por emoções alarmistas. Entrar nos pormenores e nas especificidades da argumentação de cada grupo para assumir outros pontos de vista é refutado por um discurso condenatório, pois significa dar brechas para que o outro lado ganhe força na disputa.

Neste contexto, em que a bidimensionalidade se confirma, resta ao sujeito escolher um dos lados. Posicionar-se contra o governo implica em um risco de receber a alcunha de conspirador. Ser pró-governo pode significar estar ao lado de ladrões. Com a honra e a moral em jogo, não importa qual lado escolha, o cidadão comum sente sua segurança moral e psíquica ameaçada, ativando emoções que vão dilacerar o estereótipo do brasileiro feliz e levá-lo ao combate verbal via redes sociais.

A suspeita que norteia este artigo, portanto, é que, tida como maestra desta disputa mais emotiva do que ideológica, a grande mídia dimensiona o grau emotivo com o qual os cenários devem ser interpretados, ora ajudando na desconstrução do estereótipo do brasileiro feliz quando seus interesses são ameaçados, evocando a ira e a reação, ora tentando recorrer às velhas narrativas do brasileiro feliz e outros 
regramentos quando o cenário político e econômico aproxima-se da ideologia defendida pelas famílias que a controlam.

\section{A retórica midiática como indutora de emoções}

O estudo dos impactos das emoções na construção de significados já é antigo. Quando resgatou o conceito de que "o mapa não é o território", Gregory Bateson (1987) evocou os conhecimentos de Alfred Korzibsky para explicar como nossa capacidade de generalizar, distorcer e omitir informações durante o ato de comunicar poderia gerar confusões entre o mapa cognitivo dos indivíduos. E sempre que discrepâncias ocorrem entre mapas, o estranhamento mútuo pode implicar em emoções das mais adversas.

Nosso sistema emocional está projetado para nos preparar a um estado de ação. António Damásio (2000), ao discorrer sobre a função das emoções, elucidou seu propósito ao analisar como cada emoção coloca o organismo em diferentes condições de resposta. Quando o medo é acionado, por exemplo, os batimentos cardíacos aumentam, a circulação sanguínea acelera e os músculos se retesam. Se a fuga parece ser a saída mais correta, o sujeito está pronto para sair em disparada. Se fugir já não é uma opção, o corpo está igualmente pronto para a luta, o revide e a defesa. Neste segundo estágio, o medo se torna a porta de entrada para a raiva, emoção que serve de combustível para o combate. Se as ameaças são frequentes e constantes, o sistema límbico armazena a informação da raiva como resposta mais eficaz e a etapa do medo é sobrepujada.

Sob a ótica do pensamento sistêmico de Bateson, o sistema nervoso que coloca o sujeito em estado de combate é exatamente o mesmo sistema nervoso responsável pela construção da linguagem do sujeito. É a manifestação da emoção não mais por gestos ou ações, mas por palavras.

A maioria dos estudos do fenômeno midiático atribui à forma de construção das mensagens a responsabilidade pelo grau emotivo que provoca em quem as recebe. Por sua natureza empática, o ser humano tende a aderir ao contexto emocional do que lhe é apresentado (KRZNARIC, 2015). Marshal McLuhan (2001) 
preconizou ainda nos anos 60 que "o meio é a mensagem", atribuindo ao poder retórico dos meios emissores grande responsabilidade pelos efeitos emocionais e comportamentais desencadeados na grande massa, independente do conteúdo da mensagem. Sob este prisma, assumimos que é a retórica da mensagem que dimensiona os fatos. Ou seja, ela não cria os fatos, "mas cria um clima para a interpretação dos fatos" (COSTA; FELTES, 2010).

Para os linguistas, falar em retórica significa falar em efeitos de persuasão, em criar condições de emocionalidade para o entendimento do contexto da mensagem. Assumimos neste artigo, portanto, que a retórica é o estudo das emoções na linguagem, é a compreensão do que é dito somado ao que está implícito nos atos de fala.

A retórica linguística, subárea da pragmática, apresenta mais de 300 operadores retóricos, figuras de linguagem que desempenham o papel de atribuir emoção ao discurso. "Se o argumento é o prego, a figura é o modo de pregá-lo" (REBOUL, 1998, p. 113), ou seja, são as figuras que vão dar forma à transmissão do conteúdo. Reboul classifica as figuras conforme suas relações com o discurso em que se encaixam, sendo elas as figuras de palavras, como o trocadilho, a rima, que dizem respeito à matéria sonora do discurso; as figuras de sentido, como a metáfora, que dizem respeito à significação das palavras; as figuras de construção, como a elipse ou a antítese, que dizem respeito à estrutura da frase; e as figuras de pensamento, como a alegoria, a ironia, que dizem respeito à relação do discurso com seu sujeito (o orador) ou com seu objeto (REBOUL, 2000, p. 114-115).

Estes operadores retóricos sugerem inferências sobre o conteúdo, de forma a convencer ou persuadir pela emocionalidade, independente da precisão do conteúdo. Se considerarmos que a razão opera na parte consciente da mente, e as emoções operam na parte inconsciente, podemos dizer que a retórica fala mais ao inconsciente. A retórica da persuasão coloca o indivíduo em um determinado estado emocional de forma a induzi-lo a tomar decisões e formular pensamentos a partir deste estado, e não do significado semântico do que é dito.

Agrega-se às artimanhas retóricas as propriedades semânticas que possibilitam o surgimento da linguagem, que são as propriedades de generalizar, omitir e distorcer fatos e acontecimentos. Vivemos a realidade que nosso cérebro cria 
a partir dos significados que construímos diante das percepções do mundo exterior. A partir das informações colhidas no mundo externo pelos nossos órgãos dos sentidos, "filtramos" um grande número de informações, simplificando e depois trabalhando com aquelas que são interessantes segundo nossas crenças, valores, pressuposições, entre outros fatores (CHOMSKY, 2005).

A pergunta que tem movido pesquisadores em comunicação é: quanto destes filtros são criados, induzidos e sugeridos pelos meios de comunicação? Para João Freire Filho (2015a, 2015b), Jacques Wainberg (2015), e outros pesquisadores da atualidade, as emoções eliciadas pelos construtos simbólicos midiáticos são a base deste processo. Diante de tais premissas, vale um resgate histórico de como estas estratégias de discurso ajudaram na construção do estereótipo do brasileiro feliz, bem como uma análise de como estas estratégias visam quebrar o mesmo estereótipo e substituí-lo pelo do "brasileiro revoltado" quando a ideologia dos meios está sob ameaça.

\section{$3 \mathrm{Da}$ alegria ao ódio pela retórica persuasiva}

João Freire Filho faz um interessante trabalho de pesquisa sobre como o estereótipo do brasileiro feliz foi sendo construído ao longo dos anos tanto no Brasil e no exterior (2015a) com a ajuda de crônicas, ficções, ensaios, campanhas turísticas e reportagens:

\footnotetext{
Motivo de orgulho patriótico, a típica alegria dos brasileiros foi captada e cristalizada em um singelo conjunto de imagens, ritmos e símbolos: os saracoteios do samba da Sapucaí; as ruas ocupadas por foliões eufóricos e irreverentes; garis que removem os restos da festa, bailando felizes da vida; a descontração desnuda nas praias; o jeito lúdico de praticar e de apreciar futebol; a forma risonha ou gaiata de aguentar o fardo de uma rotina de trabalhos estafantes e de direitos precários. (FREIRE FILHO, 2015a, p. 402).
}

Esta construção simbólica cristalizava as regras do que significava ser brasileiro, e sempre permeou discursos ufanistas. Em sua análise, no entanto, Freire Filho contrapõe esta visão a momentos de desconstrução da alegria brasileira ao analisar algumas reportagens do jornal $O$ Globo, do Rio de Janeiro, que contrastava 
um mau-humor repentino do carioca com a Copa do Mundo de 2014 e com os rumos políticos do País, evidenciando uma certa bipolaridade do humor típico brasileiro:

\begin{abstract}
Pacientes são diagnosticados como portadores de transtorno bipolar quando apresentam, no entendimento dos psiquiatras, graves e incapacitantes flutuações de humor, marcadas por períodos duradouros de sentimentos de tristeza, desesperança e isolamento e por fases de atividade frenética e de euforia desmedida. Na linguagem figurada de $O$ Globo, a categoria nosológica não é usada para assinalar depressões e exaltações anormais de humor - indica, antes, uma oscilação entre um quadro atípico de mau humor (ainda que associado a fatores bastante concretos) e o usual bom humor carioca (presumidamente inabalável). Delineia-se assim, um self normativo, cujo modelo superior de humor funciona, tradicionalmente, como parâmetro para avaliar padrões de condutas e atitudes, para identificar os ranzinzas, os desmancha-prazeres, os enfermos e os mau sujeitos [...]. (FREIRE FILHO, 2015a, p. 411).
\end{abstract}

Este self normativo, que balizou a alegria do brasileiro em momentos mais conservadores como o da Ditadura Militar, é colocado em contraste com estes quadros atípicos de mau humor, resultando em uma construção retórica que vai se intensificar nos últimos anos. Seria esta construção uma tentativa de passar a mensagem de que a alegria brasileira está ameaçada?

O discurso jornalístico presente nas capas das principais revistas semanais do país, como Veja e Isto É, que antecederam a abertura do processo de impeachment de Dilma Rousseff, é constituído de operadores retóricos que evocam a desconstrução do estereótipo do brasileiro feliz calcados em emoções reativas a rupturas de um estado harmônico (EKMAN, 2011).

Capas escuras, letras em vermelho, fotos manipuladas para deixar os personagens mais sombrios e manchetes que reproduzem gritos de guerra de manifestações pró impeachment dão o tom emocional com o qual o receptor deve consumir as informações. A revista Veja de 16 de março de $2016^{11}$ estampou uma foto do ex-presidente Lula com expressão raivosa, acrescida de manipulação digital que lhe confere um cabelo de medusa (em alusão à criatura da mitologia grega morta pelo herói Perseu) para expressar uma suposta irritação do presidente com as investidas da Operação Lava Jato. Em sua edição de 6 de abril de $2016^{12}$, a revista Isto $\dot{E}$ utilizou uma foto de Dilma Rousseff gritando durante um jogo do Brasil

\footnotetext{
${ }^{11}$ Edição no 2469
}

${ }^{12}$ Edição no 2417

INTERIN, v. 22, n. 2, jul./dez. 2017. ISSN: 1980-5276. 
registrada na Copa de 2014 para ilustrar o que seria um suposto descontrole emocional da presidente com assessores e aliados frente ao cenário hostil que se agravava com as chances de impeachment. A mesma revista já havia utilizado, duas semanas antes, em 23 de março de $2016^{13}$, fotos em preto e branco de Dilma e Lula com semblantes infelizes. A composição era acompanhada da manchete "Basta!", convidando o leitor a um estado de indignação (Fig. 3).

Figura 3 - Capas raivosas
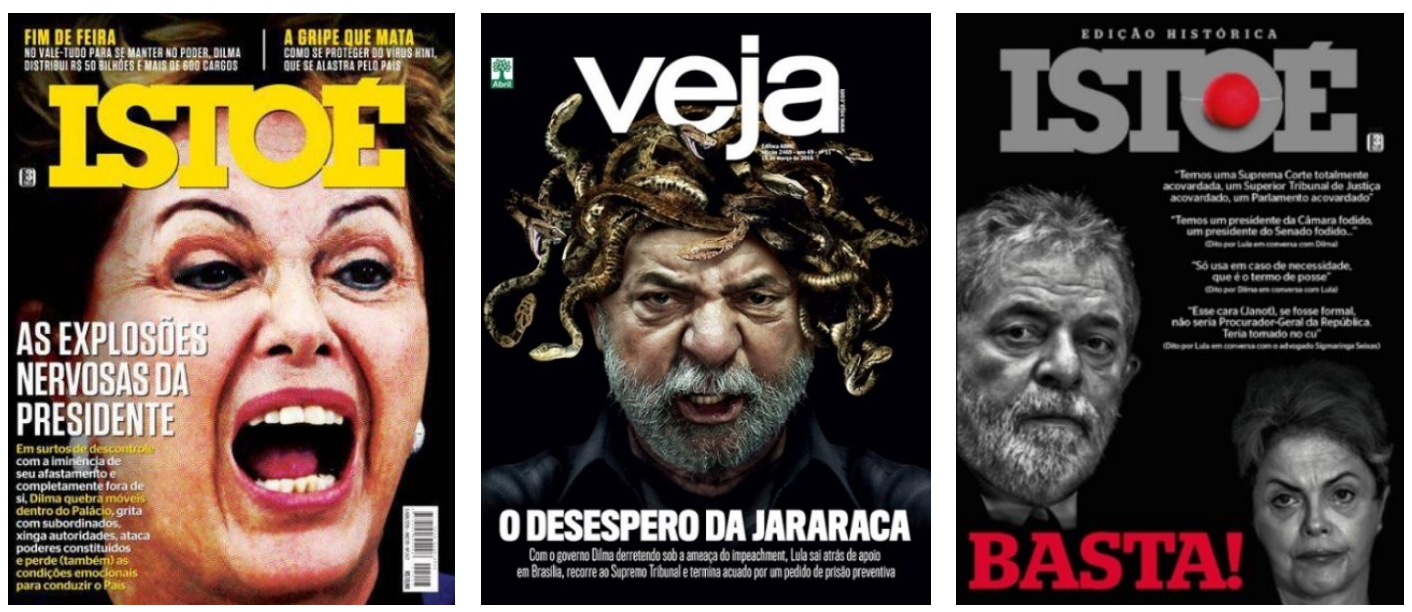

Fonte: Revistas Veja (ed. 2469 de 16/03/2016) e Isto É (ed.2417 de 06/04/2016 e 2415 de 23/03/2016).

À Dilma e Lula não apenas são atribuídas emoções que rompem com o estereótipo do brasileiro feliz, como são conferidas características vilanescas, que os colocam em oposição direta ao arquétipo do herói.

Ao mesmo tempo em que recorreram à desconstrução da alegria brasileira para falar do governo petista, as mesmas revistas seguiram um caminho diferente para abordar a possibilidade de o País ser governado pelo vice-presidente Michel Temer, do PMDB. Ainda em novembro de 2015, a revista Veja estampou o rosto de Temer com expressão serena e um leve sorriso, acompanhado da chamada "O Plano Temer". Meses antes, em julho de 2015, a concorrente Isto É já havia utilizado um estratagema semelhante ao estampar Temer em posição compenetrada, de semblante tranquilo, acompanhado da manchete "A solução Temer", atribuindo ao vicepresidente um suposto papel de "pacificador" do cenário nacional. As construções

\footnotetext{
${ }^{13}$ Edição no 2415.
}

INTERIN, v. 22, n. 2, jul./dez. 2017. ISSN: 1980-5276. 
imagéticas das duas capas são mais simpáticas, menos sombrias e mais coloridas, portanto, mais condizentes com o estereótipo do brasileiro feliz (Fig. 4).

Figura 4 - Capas esperançosas
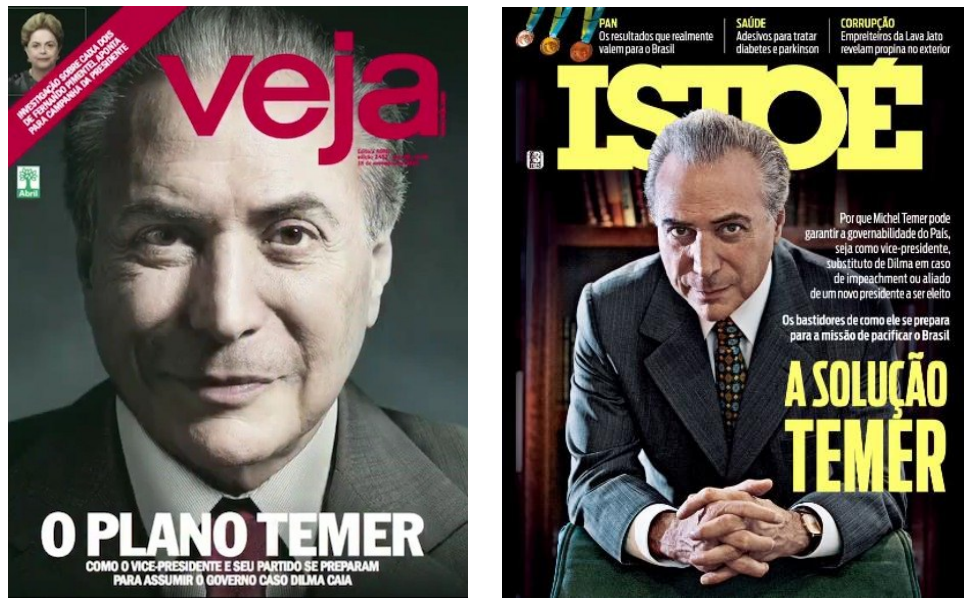

Fonte: Revistas Veja (ed. 2452 de 25/11/2015) e Isto É (ed. 2382 de 29/07/2017) ${ }^{14}$.

Num comparativo direto, podemos inferir que há uma tentativa de regrar o humor dos brasileiros por uma retórica das emoções que construa significados positivos a um possível governo Temer, mais alinhado ao jeito alegre, esperançoso e feliz do brasileiro, em contraste com as emoções de indignação, raiva e repulsa utilizadas nas capas estreladas por Dilma e Lula.

Em um documento amplamente divulgado pelos meios de comunicação de massa chamado "Uma Ponte para o Futuro", ao PMDB, com aval do então vice-presidente Michel Temer, os herdeiros do poder em um eventual sucesso do processo de impeachment propõem compromissos com uma agenda mais conservadora de governo, que contempla cortes no orçamento, incluindo o sacrifício de alguns programas sociais tidos como "marcas" dos governos do PT. "Acabar com as vinculações constitucionais" para os gastos com saúde e educação, por exemplo, é outra medida sugerida. Segundo o documento, esse tipo de despesa obrigatória foi criada por conta de um "receio de que o Executivo pudesse contingenciar" gastos em caso de necessidade. Em contrapartida, redução de

\footnotetext{
${ }^{14}$ Disponível em < http://migre.me/uxinV>. Acesso em: 07/06/2016.

${ }^{15}$ Disponível em $<$ http://agenciabrasil.ebc.com.br/politica/noticia/2015-10/pmdb-critica-excessoseconomicos-do-governo-e-aumento-de-impostos>. Acesso em: 07/06/2016.
}

INTERIN, v. 22, n. 2, jul./dez. 2017. ISSN: 1980-5276. 
impostos e incentivos ao livre mercado para aquecer a economia também estariam na pauta, o que atenderia aos anseios de empresários e industriários.

A caracterização do plano do PMDB de Temer como "solução" ou "saída para a crise" é visível na construção do discurso de capa das revistas Isto É e Veja. Mas o clima de uma possível volta da alegria para os brasileiros teve seu ápice não em matérias de economia ou política, e sim em um texto de perfil veiculado pela Veja em 18 de abril de 2016. Nele, a revista recorre à reconstrução de um estereótipo que, segundo Freire Filho (2015b), foi alimentado em paralelo ao do "brasileiro feliz" para dar o clima moral que deveria ser seguido no País ao longo do século XX, que seria o da "mulher dona de casa e feliz".

Com o título "Marcela Temer: bela, recatada e do lar", a revista enumera condutas e comportamentos da esposa de Michel Temer que a tornariam, sempre na voz de terceiros que a conhecem, como uma mulher exemplar. Em uma das passagens o texto sentencia qual o lugar de Marcela na relação com o marido:

\begin{abstract}
Em todos esses anos de atuação política do marido, ela apareceu em público pouquíssimas vezes. "Marcela sempre chamou atenção pela beleza, mas sempre foi recatada", diz sua irmã mais nova, Fernanda Tedeschi. "Ela gosta de vestidos até os joelhos e cores claras", conta a estilista Martha Medeiros. Marcela é o braço digital do vice. Está constantemente de olho nas redes sociais e mantém o marido informado sobre a temperatura ambiente. Um fica longe do outro a maior parte da semana, uma vez que Temer mora de segunda a quinta-feira no Palácio do Jaburu, em Brasília, e Marcela permanece em São Paulo, quase sempre na companhia da mãe. (LINHARES, 2016) ${ }^{16}$.
\end{abstract}

Ao enaltecer os hábitos "recatados" de Marcela, o texto busca eliciar a ternura do leitor para o lado "marido", "pai" e "poeta" de Michel Temer, ao que complementa o texto:

\footnotetext{
Amigos do vice contam que, ao fim de um dia extenuante de trabalho, é comum vê-lo tomar um vinho, fumar um charuto e "mergulhar num outro mundo" - o que ocorre, por exemplo, quando telefona para Marcela ou assiste a vídeos de Michelzinho [filho do casal] ${ }^{17}$, que ela manda pelo celular. Três anos atrás, Temer lançou o livro de poemas intitulado Anônima Intimidade. Um deles, na página 135, diz: "De vermelho / Flamejante / Labaredas de fogo / Olhos brilhantes / Que sorriem / Com lábios rubros / Incêndios / Tomam conta de mim / Minha mente / Minha

${ }^{16}$ Disponível em $<$ http://veja.abril.com.br/noticia/brasil/bela-recatada-e-do-lar>. Acesso em: 07/06/2016.

${ }^{17}$ Grifo dos autores.
}

INTERIN, v. 22, n. 2, jul./dez. 2017. ISSN: 1980-5276. 
alma / Tudo meu / Em brasas / Meu corpo / Incendiado / Consumido / Dissolvido / Finalmente / Restam cinzas / Que espalho na cama / Para dormir. (LINHARES, 2016)" ${ }^{\prime 18}$.

A última frase do texto de perfil afirma: "Michel Temer é um homem de sorte".

Figura 5: Marcela Temer: bela, recatada e "do lar"

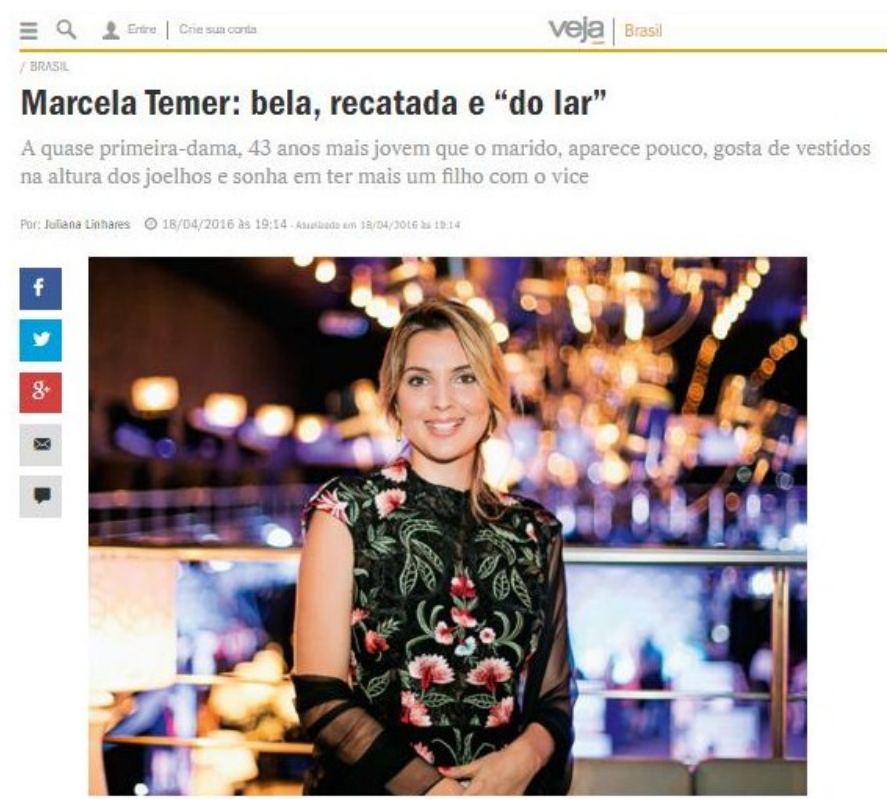

Fonte: Site da Revista Veja ${ }^{19}$

Freire Filho (2015b) lembra que o cenário político suscitado pela primeira onda feminista, ainda no século XIX, teria impulsionado o discurso de afirmação da felicidade como um bem emocional e econômico dos lares da classe média, em que a esposa alegre representaria a oposição às novas militantes infelizes e raivosas da época. No século XX, revistas dos anos 50 retratavam a realização da mulher no papel de esposa e de dona de casa. Sessenta anos depois, como mostra Veja, as donas de casa permanecem no ideário das representações midiáticas ditas conservadoras.

Em artigo recente, Freire Filho (2015b) mostra que o ideal da dona de casa feliz permeia a linha editorial de Veja já há algum tempo. Ele cita reportagens e

\footnotetext{
${ }^{18}$ Disponível em http://veja.abril.com.br/noticia/brasil/bela-recatada-e-do-lar>. Acesso em: 07/06/2016.

${ }^{19}$ Idem.
} 
artigos publicados pela revista que enaltecem as conquistas femininas ao mesmo tempo em que estabelece uma queda da felicidade das mulheres ao longo do tempo. Dentre as hipóteses da revista para tal fenômeno, Freire Filho destaca a seguinte.

\begin{abstract}
Se, na década de 1950 , as preocupações giravam em torno do âmbito doméstico e das questões de beleza, hoje fatores como 'ter sucesso no trabalho', 'contribuir para a sociedade' e 'ser uma líder na minha comunidade' se tornam fundamentais, sem que as demandas antigas deixem de ser relevantes. (FREIRE FILHO, 2015b, p. 12).
\end{abstract}

A estratégia de Veja recorrer a estereótipos para eliciar o clima emocional em torno de Marcela Temer, no entanto, encontrou resistência nas redes sociais. $\mathrm{O}$ tom estereotipado do perfil sobre a esposa do então vice-presidente foi recebido com ironia, indignação e acusações de misoginia e sexismo por parte de ativistas feministas. Internautas criaram memes ${ }^{20}$ e uma página no Tumblr para mostrar, em claro tom de deboche, suas versões nada conservadoras do que seriam as mulheres "belas, recatadas e do lar" dos tempos modernos (Fig. 6).

Figura 6: Tumblr em "homenagem" à Marcela Temer

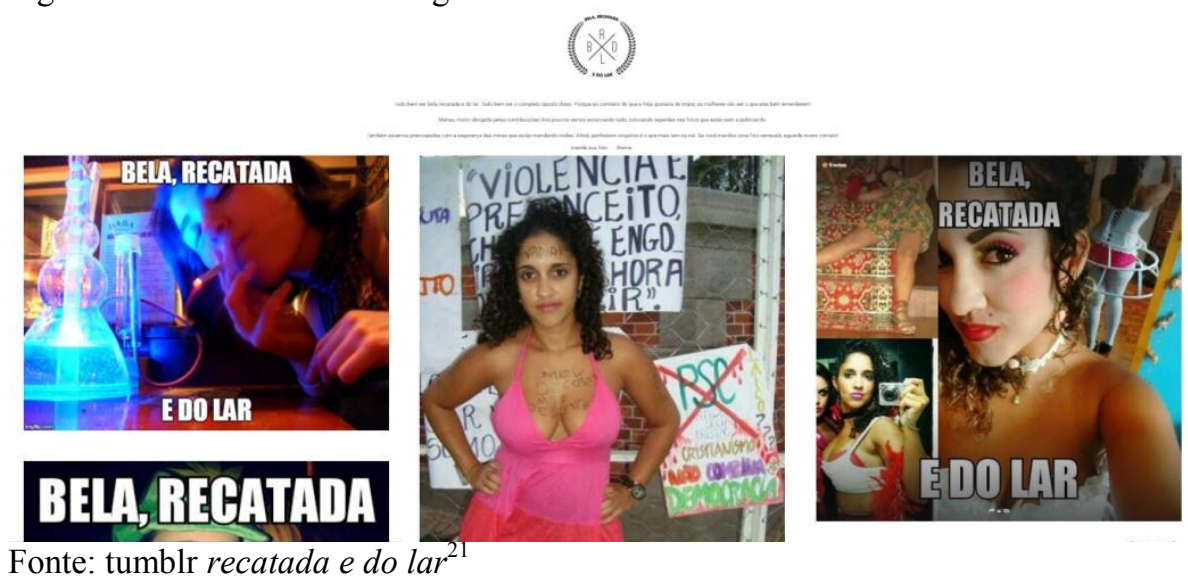

A aparente falta de adesão ao regramento emocional proposto por Veja no caso da matéria de perfil de Marcela Temer demonstra que há uma contra força de significações operando no imaginário coletivo brasileiro. A própria Veja noticiou os memes em seu site, mas dando a entender que parte do que foi construído na narrativa de perfil era uma ironia, mas que compreendia a divergência de opiniões e

\footnotetext{
${ }^{20}$ Conceito atribuído a materiais recriados e compartilhados nas redes sociais.

${ }^{21}$ Disponível em <http://belarecatadaedolar.tumblr.com/>. Acesso em: 07/06/2016.
}

INTERIN, v. 22, n. 2, jul./dez. 2017. ISSN: 1980-5276. 
de manifestações nas redes sociais, classificando tudo como manifestações de bom humor, como mostra o texto a seguir:

Há quem considere que a reportagem endossa o modo de vida de Marcela Temer, e é machista. Outros leram a ironia. E outros ainda simplesmente aproveitaram o título para fazer humor. A interpretação é livre. Esta página reproduz os memes mais engraçados. (REDAÇÃO VEJA, 2016) ${ }^{22}$.

As opiniões divergentes e polarizadas sobre o cenário político e econômico e a resistência ao estabelecimento de regras e padrões de comportamento passam pelo poder disseminador das redes sociais como um reduto de construções diversificadas que estão dispostas a questionar, seja pelo humor ou pelo discurso combativo, uma retórica midiática que faz uso de estereótipos para eliciar emoções de forma persuasiva. Neste sentido, Freire Filho define bem a internet como um "recanto de anônimos ressentidos".

[...] a internet parece ter escancarado aversões latentes a "sentimentos feios" (NGAI, 2005) encobertos, costumeiramente, pelas máscaras sociais da alegria brasileira. Redes sociais virtuais - concebidas para o compartilhamento de memórias aprazíveis, instantes festivos, mensagens e produtos "inspiradores" - acabam servindo, também, para dar vazão a um volume notável de comentários e testemunhos raivosos que escapam, inteiramente, da proposta de contágio emocional positivo. Facebook, Youtube e outras plataformas da felicidade on-line se convertem, amiúde, em caixas de ressonância da fúria de legiões de consumidores e cidadãos revoltados. (FREIRE FILHO, 2015a, p. 414).

\section{Conclusão}

Se ao longo do século $\mathrm{XX}$ os meios de comunicação de massa exerciam um papel soberano na construção do clima emocional brasileiro, hoje os mesmos meios tentam se adaptar à voz dada ao receptor desde a massificação da internet e do advento das redes sociais.

Em 2013, os veículos mais conservadores viram nas manifestações pela redução das passagens de ônibus que ocorreram em diversas capitais do Brasil uma oportunidade de inflamar a população de forma a direcionar uma grande revolta

\footnotetext{
${ }^{22}$ Disponível em $<$ http://veja.abril.com.br/noticia/vida-digital/belarecatadaedolar-os-memes-sobre-areportagem-de-veja>. Acesso em: 07/06/2016
}

INTERIN, v. 22, n. 2, jul./dez. 2017. ISSN: 1980-5276. 
contra um governo cujas políticas classificam como "populistas". Agora estes mesmos veículos encontram dificuldades em apaziguar os ânimos para restabelecer qualquer ordem desejada. Como constata Freire Filho, "a desinibida virulência das interações virtuais contribui para estremecer os alicerces da 'imagem mítica do brasileiro simpático"” (2015a, p. 414).

Se realmente existe um modos operandi midiático que tenta regrar o humor da população pela construção e desconstrução dos estereótipos sacralizados no passado do povo brasileiro, hoje o ambiente virtual funcionaria como um espelho da alma brasileira ou, como afirma Freire Filho, "uma janela que permite contemplar, diretamente, nossas emoções mais autênticas" (2015a, p. 415), o que tiraria dos meios de comunicação de massa parte deste suposto poder controlador sobre as emoções que regram o humor nacional.

Isto não significa que os meios de comunicação de massa abriram mão de tal estratégia, pelo contrário. Em entrevista dada exclusivamente ao repórter Kennedy Alencar, do telejornal SBT Brasil, veiculada em 28 de abril de 2016, e reproduzida em partes pelo jornal $O G l o b o^{23}$, Michel Temer admitiu não concorrer à reeleição, caso assumisse a presidência em definitivo, em nome de um bem maior, que seria a recuperação da economia e o encerramento dos conflitos. Como argumento central, recorreu ao velho estereótipo que há quase um século é usado para normatizar o humor do brasileiro. Afirma Temer:

Ficaria felicíssimo se ao final de um eventual governo, eu conseguisse colocar o país na rota do crescimento, conseguisse pacificar, não podemos mais ter essa coisa de brasileiros contra brasileiros, se eu conseguisse dar uma certa harmonia à sociedade, que o Brasil voltasse a ser um país alegre. (REDAÇÃO O GLOBO, 2016) ${ }^{24}$.

Campo da informação e da desinformação, onde a verdade, a mentira e os contraditórios ganham mesmo peso e mesma medida, como já alertou Andrew Keen (2009), a internet, em sua dinâmica com os meios tradicionais de comunicação de massa, torna-se uma força contrária aos regramentos da grande mídia, originando um

\footnotetext{
${ }^{23}$ Disponível em <http://oglobo.globo.com/brasil/temer-diz-que-abre-mao-da-reeleicao-em-201819193379>. Acesso em: 07/06/2016.

${ }^{24}$ Grifo dos autores.
}

INTERIN, v. 22, n. 2, jul./dez. 2017. ISSN: 1980-5276. 
vasto campo de estudos na desconstrução de imagens, mitos, utopias e estereótipos (WAINBERG, 2015).

Cabe aos pesquisadores da comunicação desvendar como as emoções são ativadas e transformadas neste complexo ir e vir de informações em rede, que aparentemente se tornam cada vez mais voláteis e determinantes na construção de sentidos que vão compor o imaginário coletivo brasileiro.

\section{REFERÊNCIAS}

BATESON, Gregory. Natureza e espírito: uma unidade necessária. Lisboa: Dom Quixote, 1987.

CHOMSKY, N. Novos horizontes no estudo da linguagem e da mente. São Paulo: Editora Unesp, 2005.

COSTA, Jorge C.; FELTES, Heloísa P.M. Filosofia da Linguística, filosofia da ciência e os pressupostos para a construção de uma Metateoria das Interfaces. In: ARAÚJO, J.C.; BIASI-RPDRIGUES, B.; DIEB, M. Seminários Linguísticos: discurso, análise linguística, ensino e pesquisa. Mossoró: Edições UERN, 2010. p. 341-355.

DAMÁSIO, António. O mistério da consciência: do corpo e das emoções ao conhecimento de si. São Paulo: Companhia das Letras, 2000.

EKMAN, Paul. A linguagem das emoções. São Paulo: Lua de Papel, 2011.

FREIRE FILHO, João. Era uma vez o "país da alegria": mídia, estados de ânimo e identidade nacional. Intexto, Porto Alegre, n. 34, p. 401-420, set./dez. 2015a. Edição especial.

FREIRE FILHO, João. "Mas por que, afinal, as mulheres não sorriem?": Jornalismo e as razões da (in)felicidade feminina. Ciberlegenda, Niterói, v. 33, n. 2, p. 8-20, $2015 b$.

JUDENSNAIDER, Helena et al. Vinte Centavos: a luta contra o aumento. São Paulo: Veneta, 2013.

KEEN, Andrew. O culto do amador. Rio de Janeiro: Jorge Zahar, 2009.

KRZNARIC, Roman. O poder da empatia: a arte de se colocar no lugar do outro para transformar o mundo. Tradução de: BORGES, Maria Luiza X. de A. 1. ed. Rio de Janeiro: Zahar, 2015. 
LINHARES, Juliana. Marcela Temer: bela, recatada e "do lar". São Paulo: Veja. 18 de abril de 2016. Disponível em $<$ http://veja.abril.com.br/brasil/marcela-temer-belarecatada-e-do-lar/>. Acesso em 07 mai. 2016.

McLUHAN, Marshall. Os meios de comunicação como extensões do homem. Tradução de: PIGNATARI, Décio. São Paulo: Cultrix, 2001 [1964].

MIRANDA, David. A razão pela qual os inimigos de Dilma Rousseff querem o seu Impeachment. Londres: The Guardian, Sexta-feira, 22 de abril de 2016. Disponível em <http://www.theguardian.com/commentisfree/2016/apr/22/razao-real-que-osinimigos-de-dilma-rousseff-querem-seu-impeachment>. Acesso em 07 mai. 2016.

REBOUL, Olivier. Introdução à retórica. São Paulo: Martins Fontes, 1998.

REDAÇÃO O GLOBO. temer diz que abre mão da reeleicao em 2018. Rio de Janeiro: O Globo. 28 abr. 2018. Disponível em $<$ http://oglobo.globo.com/brasil/temer-diz-que-abre-mao-da-reeleicao-em-201819193379>. Acesso em 07 mai. 2016.

REDAÇÃO VEJA. \#belarecatadaedolar: os memes sobre a reportagem de VEJA. São Paulo: Veja. 20 abr. 2016. Disponível em $<$ http://veja.abril.com.br/tecnologia/belarecatadaedolar-os-memes-sobre-areportagem-de-veja/>. Acesso em 07 mai. 2016.

WAINBERG. Jacques Alkalai. Revolucionários, mártires e terroristas: a utopia e suas consequências. São Paulo: Paulus, 2015.

Recebido em: 07.06.2016

Aceito em: 20.09.2016 